\title{
PA-054 CORRELATION OF HIV-1 P24 ASSAY WITH CD4 T-CELL COUNT, HIV, HBV AND HCV CO-INFECTIONS AND ITS IMPLICATION FOR ART MONITORING IN VASTLY HIV-INFECTED POPULATION OF NIGERIA
}

Iheanyi Okonko, ${ }^{1}$ Phillip Okerentugba, ${ }^{1}$ Oluyinka Opaleye, ${ }^{2}$ Ezinwanne Awujo, ${ }^{1}$ Nnenna Frank-Peterside 1 . 'University of Port Harcourt, Nigeria; ${ }^{2}$ LAUTECH, Nigeria

10.1136/bmjgh-2016-000260.87

Background Reports indicate that extensive genetic diversity of HIV-1 impacts almost every aspect of HIV-1 epidemiology, including laboratory detection, ART/resistance, monitoring of ART and vaccine development. Therefore, in order to support the scale-up of access to HAART to mitigate the HIV-1 scourge, prompt, accurate and cost-effective diagnosis and monitoring of ART is crucial in Nigeria (a resource-limited country).

Methods Plasma of 200 confirmed HIV-1 patients on a specified and uniform ART regimen was monitored with P24 antigen assay and CD4 T-cell count as virologic and immunologic assessments of response to ART. The results of the assays (P24 and CD4 count) were compared to assess sensitivity, turn-around time and financial advantages of P24 over the CD4 count. Serological analysis of HBV and HCV were performed according to the manufacturer's instructions. Enumeration of CD4+ levels was done with a Partec flow cytometer.

Results Of these patients, $77.5 \%$ had HIV only, $14.5 \%$ had HIV-HBV and $11.5 \%$ had HIV-HCV. Evaluation of levels of P24 antigen revealed that lower limits for P24 antigen 0.5772.308 were detected in the subjects with CD4 cell count $>500$. However, higher limits for P24 antigen 2.308-2.885 were detected in subjects with CD4 cell count within the range of 200-499. Correlation analysis showed an inverse relationship between CD4 count and level of P24 antigen (CD4 count of $200-499$ cells $/ \mu \mathrm{l}$ versus $2.308-2.885$ of $\mathrm{P} 24, \mathrm{r}=-0.319, \mathrm{CD} 4$ count $\geq 500$ cells $/ \mu$ l versus $0.577-2.307$ of $\mathrm{P} 24, \mathrm{r}=-0.088$ ).

Conclusions This study suggests that p24 could serve as one of such diagnostic and monitoring facilities that could be used in a 


\section{Abstracts}

resource-limited area like Nigeria. This will in turn lead to selection of more specific ARV options that best suppress viraemia during initiation of ART, as well as for monitoring HIV-1 patients in Nigeria, knowing that the virus subtype impacts effectiveness of ART. 